\title{
An experimental study of the decomposition of steenstrupine in $\mathrm{Na}_{2} \mathrm{CO}_{3}$ solution
}

\author{
Jens Konnerup-Madsen, Paul Martin Holm and John Rose-Hansen
}

This study is part of a more detailed investigation of the stability and the natural decomposition process of steenstrupine, initiated to help delineate the conditions during the later stages of solidification of the Ilímaussaq rocks. Interest in steenstrupine also arises from the potential importance regarding Kvanefjeld as a uranium ore reserve, steenstrupine being the most important uranium-bearing mineral in the Kvanefjeld area (Sørensen et al., 1974; Makovicky, 1981). Major emphasis has been placed on the decomposition of steenstrupine in $\mathrm{Na}_{2} \mathrm{CO}_{3}$ solution in the $200^{\circ}$ to $600^{\circ} \mathrm{C}$ range at pressures up to 1000 bars.

\section{Experimental methods and materials}

The hydrothermal runs are made in 12-inch 'cold-seal' bombs (Tuttle, 1949) heated externally in vertical resistance furnaces. Quenching is carried out by applying compressed air followed by immersion in water, resulting in a quenching time to room temperature of less than 3 minutes. Temperatures are measured with calibrated internal thermocouples and are considered accurate to within $\pm 2^{\circ} \mathrm{C}$ of the recorded value. Measurements indicate that the thermal gradient in the sample region does not exceed $10^{\circ} \mathrm{C}$ over the temperature and pressure range of this study. Pressure is measured with a transducer and is considered accurate to \pm 10 bars.

Charges consist of coarsely ground $(0.25-0.5 \mathrm{~mm})$ steenstrupine and added solution of $\mathrm{Na}_{2} \mathrm{CO}_{3}$, and also $\mathrm{NaHCO}_{3}, \mathrm{NaCl}$, and mixtures of these. The charges are sealed in gold capsules and consist of about $30 \mathrm{mg}$ steenstrupine and $30-100 \mathrm{mg}$ solution. A few runs were made with controlled oxygen fugacity using the conventional double capsule technique (Huebner, 1971) and hematite + magnetite as buffer. After quenching the capsules are cut open and the content washed out and filtered. The nature of the solid products is ascertained by standard methods of optical, X-ray and microprobe analysis. The solutions are analysed for uranium with delayed neutron activation analysis.

The steenstrupine concentrate used comes from a steenstrupine-rich analcime-albiteaegirine pegmatite (GGU 199104) collected by S. Karup-Møller (DTH). The chemical composition of the steenstrupine as determined by microprobe analysis is given in Table 1 .

The choice of solutions used in the experiments was based on the presence of trona and thermonatrite, occasionally associated with villiaumite, in cavities in drill cores from the Kvanefjeld area (Sørensen et al., 1970), and from the presence of saturated $\mathrm{NaCl}$ solutions in fluid inclusions in minerals (Konnerup-Madsen et al., 1979).

\section{Experimental results}

The results of the experiments have up till now been evaluated primarily in terms of the concentration of uranium in solution after runs as this value a priori was considered to 
Table 1. Concentration of uranium in solutions coexisting with steenstrupine and experimental conditions of runs

\begin{tabular}{|c|c|c|c|c|c|c|}
\hline RUN & $\begin{array}{l}\text { TEMPERATURE } \\
{ }^{\circ} \mathrm{C}\end{array}$ & $\begin{array}{l}\text { PRESSURE } \\
\text { BARS }\end{array}$ & $\begin{array}{l}\text { TIME } \\
\text { HOURS }\end{array}$ & BUFFER" & SOLUTION & $\begin{array}{l}\text { U CONCENTRATION" } \\
{ }_{\nu G / M L}\end{array}$ \\
\hline 43 & 200 & 1000 & 144 & - & $1 M \mathrm{NA}_{2} \mathrm{CO}_{3}$ & 251.9 \\
\hline 32 & 207 & 1000 & 144 & - & 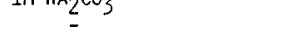 & 770.1 \\
\hline 42 & 250 & 500 & 144 & - & - & 197.6 \\
\hline 16 & 292 & 500 & 144 & - & - & 479.5 \\
\hline 44 & 300 & 1000 & 24 & - & - & 1063.8 \\
\hline 45 & 304 & 1000 & 46 & - & - & 256.4 \\
\hline 46 & 300 & 1000 & 96 & - & - & 269.9 \\
\hline 17 & 300 & 1000 & 144 & - & - & 478.7 \\
\hline 47 & 300 & 1000 & 144 & + & - & 584.6 \\
\hline 33 & 360 & 1000 & 144 & - & - & 405.1 \\
\hline 01 & 403 & 500 & 145 & + & - & 90.0 \\
\hline 02 & 417 & 500 & 145 & - & - & 65.5 \\
\hline 12 & 402 & 500 & 144 & + & - & 17.6 \\
\hline 22 & 391 & 1000 & 144 & + & - & 15.0 \\
\hline 15 & 404 & 1000 & 144 & - & - & 68.4 \\
\hline 08 & 480 & 500 & 143 & - & - & 111.5 \\
\hline 30 & 493 & 250 & 140 & - & - & 71.7 \\
\hline 31 & 498 & 750 & 140 & - & - & 47.5 \\
\hline 19 & 502 & 1000 & 47 & - & - & 29.3 \\
\hline 20 & 490 & 1000 & 72 & - & - & 15.9 \\
\hline 29 & 492 & 1000 & 141 & - & - & 9.3 \\
\hline 25 & 496 & 1000 & 144 & - & - & 10.2 \\
\hline 21 & 495 & 1000 & 238 & - & - & 7.6 \\
\hline 14 & 607 & 500 & 144 & - & - & 11.3 \\
\hline 23 & 590 & 1000 & 142 & - & - & 8.8 \\
\hline 34 & 278 & 1000 & 141 & - & $1 \mathrm{M} \mathrm{NaHCO}_{3}$ & 797.1 \\
\hline $\begin{array}{l}34 \\
49\end{array}$ & 300 & 1000 & 144 & - & 1000 PPM NAF & 395.8 \\
\hline 40 & 314 & 1000 & 168 & - & $1 M \mathrm{Na}_{2} \mathrm{CO}_{3}+10 \mathrm{PPM}$ NAF & 222.2 \\
\hline 39 & 309 & 1000 & 167 & - & IM NA2C03 + 100 PPM NAF & 31,5 \\
\hline 38 & 302 & 1000 & 166 & _- & $1 M N_{A 2} C_{3}+1000$ PPM NAF & 145.8 \\
\hline 26 & 484 & 1000 & 144 & _- & $\mathrm{H}_{2} \mathrm{O}$ & 9.2 \\
\hline 36 & 493 & 1000 & 143 & - & $0.01 M \mathrm{NA}_{2} \mathrm{CO}_{3}$ & 32.5 \\
\hline 28 & 495 & 1000 & 141 & - & $0.1 \mathrm{M} \mathrm{NA}_{2} \mathrm{CO}_{3}$ & 15.8 \\
\hline 37 & 506 & 1000 & 143 & - & IM NACL & 22.3 \\
\hline
\end{tabular}

\footnotetext{
* apPlication/NON-APPlication of hematite + Magnetite BuffER INDICATED BY +/-

* "urani um concentrations calculated on the basis of the concentration in the first LEACHATE. EXPERIMENTS SHOWED THIS TO ACCOUNT FOR MORE THAN $97 \%$ OF THE TOTAL AMOUNT OF URANIUM OBTAINED BY SUCCESSIVE LEACHINGS OF RUN MATERIAL, LEACHING PERFORMED WITH DOUBLE-DISTILLED, DEIONIZED WATER.
}

respond approximately to the degree of decomposition of steenstrupine. The results are listed in Table 2 together with the experimental conditions and are presented graphically in fig. 1 .

The solid run products have at present only been cursorily examined. Steenstrupine is present in all runs and even at the highest temperatures only a roughly $10 \mu \mathrm{m}$ wide reaction rim constitutes the main optical difference from the starting material. Monazite was indicated by X-ray diffraction in all runs above approximately $300^{\circ} \mathrm{C}$. Thermonatrite was identified in all runs with $\mathrm{Na}_{2} \mathrm{CO}_{3}$ solutions and is typically present in the form of about $20 \mu \mathrm{m}$ long quench rosettes or thin plates and needles. In addition to these phases colourless, apparently 
Table 2. Microprobe analyses of steenstrupine in experimental studies

\begin{tabular}{|c|c|c|c|c|c|c|c|c|}
\hline & \multirow{2}{*}{$\begin{array}{l}\text { STARTING } \\
\text { MATERIAL } \\
\end{array}$} & \multirow{2}{*}{$\begin{array}{l}200^{\circ} \mathrm{C} \\
\text { CENTRE }\end{array}$} & \multirow{2}{*}{$\begin{array}{c}\text { RUN } 32 \\
\text { RIM } \\
\end{array}$} & \multirow{2}{*}{$\begin{array}{l}400^{\circ} \mathrm{C} \\
\text { CENTRE }\end{array}$} & \multirow{2}{*}{$\begin{array}{c}\text { RUN } 22 \\
\text { RIM }\end{array}$} & \multicolumn{3}{|c|}{$500^{\circ} \mathrm{C} \quad$ RUN 25} \\
\hline & & & & & & CENTRE & RIM & MINERAL $X$ \\
\hline$N_{A}$ & 2.2 & 3.0 & 8.0 & 9.4 & 9.0 & 12.5 & 13.0 & 1.4 \\
\hline AL & 0.4 & ND & ND & 0.3 & 0.3 & 0.3 & 0.4 & 0.1 \\
\hline SI & 13.3 & 14.4 & 12.0 & 11.1 & 1.1 .7 & 10,0 & 12.0 & 22.7 \\
\hline$P$ & 5.0 & 5.5 & 5.3 & 5.8 & 5.4 & 5.0 & 4.4 & 0.0 \\
\hline$C_{A}$ & 1.5 & 1.7 & 1.8 & 2.0 & 2.0 & 1.7 & 1.9 & 0.1 \\
\hline TI & 0.2 & 0.2 & 0.2 & 0.2 & 0.1 & 0.2 & 0.1 & $<0.07$ \\
\hline$M_{N}$ & 3.4 & 5.0 & 3.0 & 3.0 & 5.3 & 3.5 & 3.0 & $<0.08$ \\
\hline $\mathrm{FE}$ & 3.3 & 3.7 & 3.0 & 6.5 & 2.0 & 2.5 & 5.0 & $<0,07$ \\
\hline Y & 0,3 & 0.4 & 0.3 & 0.1 & 0.3 & 0.1 & 0.2 & 0.9 \\
\hline$Z_{R}$ & 1.3 & 3.9 & 1.0 & 3.0 & 4.2 & 3.1 & 1.9 & $<0,27$ \\
\hline LA & 9.3 & ND & ND & 10.9 & 9.0 & 10.2 & 8.2 & 2.6 \\
\hline$C_{E}$ & 13.6 & 14.2 & 11.0 & 14.0 & 15.9 & 15.8 & 14.0 & 7.4 \\
\hline$P_{R}$ & 1.9 & 1.7 & 1.8 & 2.6 & 1.8 & 1.9 & 1,9 & 0.9 \\
\hline$N D$ & 9.3 & 9.2 & 8.0 & 9.9 & 11.0 & 9.6 & 10.0 & 4.5 \\
\hline $\mathrm{TH}_{\mathbf{H}}$ & 4.0 & 4.1 & 4.7 & 3.2 & 4.1 & 4.5 & 3.7 & 2.2 \\
\hline
\end{tabular}

NOTES: ND NOT DETERMINED

< BELOW DETECTION LIMIT AS STATED

NB determined but in all CASES below detection Limit (0.23 Weight PCT.)

orthorhombic crystals showing moderate birefringence were observed to have grown on the rims of steenstrupine grains in all runs with $\mathrm{Na}_{2} \mathrm{CO}_{3}$ solution at temperatures above approximately $300^{\circ} \mathrm{C}$. These crystals are up to $10 \mu \mathrm{m}$ long and show slight effervescence in dilute $\mathrm{HCl}$. They occur in increasing amounts with increase in run temperature. An average microprobe analysis of this mineral $\mathrm{X}$ is given in Table 2 together with microprobe analyses of steenstrupine grains obtained at $200^{\circ}, 400^{\circ}$ and $500^{\circ} \mathrm{C}$ and the starting steenstrupine material.

\section{Discussion of results}

The most significant result of the present preliminary experiments is the marked decrease in uranium concentration in $1 \mathrm{M} \mathrm{Na}_{2} \mathrm{CO}_{3}$ solutions in contact with steenstrupine with increase in temperature (fig. $1 \mathrm{~A}$ ). Similar results are obtained with other solution types and with $\mathrm{IM}$ $\mathrm{Na}_{2} \mathrm{CO}_{3}$ solutions buffered to hematite-magnetite oxygen fugacities (fig. $1 \mathrm{~B}$ ). The lack of influence from hematite-magnetite buffering of the oxygen fugacity may, however, be due to a combination of low temperatures and short durations of experiments (Ulmer, 1971, pp. 140-141). Variations in pressures do not appear to influence the results in any systematic way (fig. $1 \mathrm{~A}$ ).

In a strict sense the relations expressed in fig. 1 only apply to an experimental duration of about 6 days. Runs at $300^{\circ}$ and $500^{\circ} \mathrm{C}$ at 1000 bars with the duration of runs from 1 to 10 days 

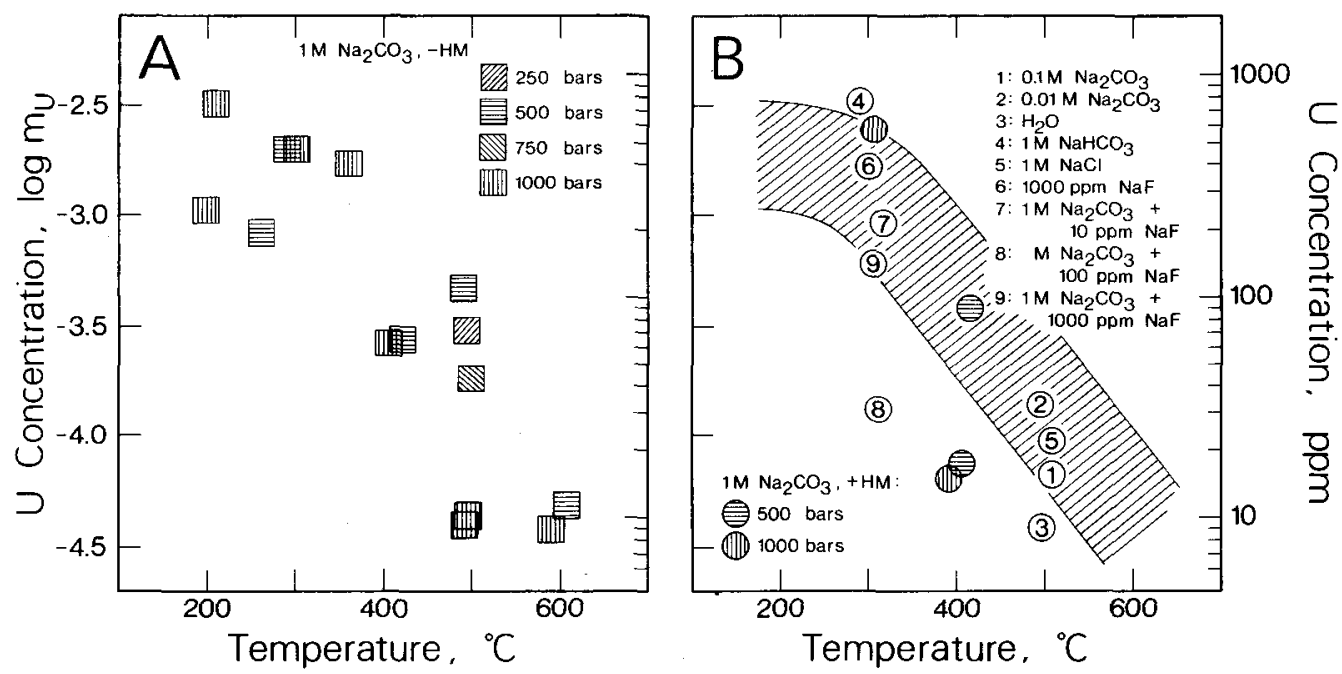

Fig. 1. Concentration of uranium (shown both on a $\log ($ mole $U$ ) and a ppm scale) in solutions coexisting with steenstrupine versus temperature. (A) Results for $1 \mathrm{M} \mathrm{Na}_{2} \mathrm{CO}_{3}$ solutions at various pressures as shown in figure, with an experimental duration of 6 days and no buffering of oxygen fugacity (-HM). (B) Results for various solutions with an experimental duration of 6-8 days at a pressure of 1000 bars, and for $1 \mathrm{M} \mathrm{Na}_{2} \mathrm{CO}_{3}$ solutions buffered with hematite-magnetite $(+\mathrm{HM})$ at the pressures shown.

show variations in the concentration of uranium in solution (Table 1). Whereas the results at $300^{\circ} \mathrm{C}$ (runs $44,45,46$, and 47 ) are ambiguous, the results at $500^{\circ} \mathrm{C}$ (runs $19,20,29,25$, and 21) show a marked decrease in concentration with the length of the experiment but with a levelling out for run durations around 6 days (Table 1). These experiments indicate disequilibrium and hence the results do not depict maximum uranium concentrations but the values corresponding to the stated experimental duration. The observed decrease in concentration of uranium in solution with increasing temperature and with increase in time at $500^{\circ} \mathrm{C}$ may be tentatively linked with the (kinetics of) formation of the unidentified phase (mineral X, Table 1) on the rims of steenstrupine grains. As this phase is richer in uranium than the coexisting steenstrupine (Table 1, last columns) its formation would tend to lower the amount of uranium in solution at higher temperatures.

The main changes in composition of steenstrupine with temperature are the large increase in $\mathrm{Na}$ and the slight decrease in Si. The decrease in the uranium content of steenstrupine is already observed at $200^{\circ} \mathrm{C}$ and hence supports the proposal that the decrease in uranium in solution at higher temperatures is in part due to incorporation of uranium in other phases such as monazite and/or mineral $X$ (Table 1 ).

Microprobe analyses of mineral $X$ (average analysis given in Table 1) show it to be very inhomogeneous in composition, especially regarding $U$ and the relative amounts of the REE, whereas $\mathrm{Si}$ appears to be very constant. Inspection of the chemical analyses suggests this mineral to be a tectosilicate. Based on the chemical compositions, and taking the nature of the coexisting solutions into consideration, calculations indicate that this phase may tentatively be described as a $\mathrm{Na}(\mathrm{REE}, \mathrm{Th}, \mathrm{U})_{2}\left(\mathrm{SiO}_{2}\right)_{13}$-carbonate/bicarbonate. The incor- 
poration of carbonate ions possibly takes place only at the considerable pressures of carbon dioxide obtained in the higher temperature runs. However, further data on this phase are needed in order to characterize it more thoroughly.

\section{Concluding remarks}

The study indicates that treatment of steenstrupine with $\mathrm{Na}_{2} \mathrm{CO}_{3}$ solutions does not involve a destruction of steenstrupine but that it can respond by changes in composition without significant structural changes. The concentration of uranium in solution in contact with steenstrupine furthermore does not merely reflect equilibrium with steenstrupine but is affected by formation of other phases such as monazite and/or a possibly new phase (mineral $\mathrm{X})$.

In the Ilímaussaq intrusion rim zones of zoned crystals of steenstrupine are often deficient in uranium compared to the central parts, suggesting that oxidation of rims formed $\mathrm{UO}_{2}^{2+}$ and that some of the uranium was then removed by leaching (Sørensen, 1962). Studies by Buchwald \& Sørensen (1961) and by Makovicky et al. (1979) show that the higher uranium contents are observed in the most altered parts of the steenstrupine grains. The present study shows a leaching process to be most effective at comparatively low temperatures. Similar relations between uranium in solution and temperature as depicted in fig. 1 were observed by Lemoine (1975) and Naumov (1961) for $\mathrm{UO}_{2}$ and $\mathrm{UO}_{3}$ in $\mathrm{NaHCO}_{3}$ solutions and were explained in terms of equilibria involving carbonate ion complexing. In the present experiments similar relations are considered likely but have in part been blurred by formation of (and equilibrium with) other uranium-bearing phases.

Acknowledgements. The financial support provided by the Danish Natural Science Research Council (J.Nr. 511-10210/516), the Danish Technical Research Council (J.Nr. 10015K/417) and the EEC Uranium R \& D Programme (Project Nr. 018/79/1) is gratefully acknowledged. The authors thank the Ris $\varnothing$ National Laboratory for undertaking the uranium analyses.

Thanks are also due to J. C. Bailey and $\mathrm{H}$. Sørensen for comments and criticism of the manuscript.

E. Johannsen, Risø National Laboratory, is acknowledged for his valuable technical assistance with the $\gamma$-ray spectrometry and the delayed-neutron analyses.

\section{References}

Buchwald, V. \& Sørensen, H. 1961: An autoradiographic examination of rocks and minerals from the Ilímaussaq batholith, South West Greenland. Bull. Grønlands geol. Unders. 28 (also Meddr Grønland 162,11) 35 pp.

Huebner, J. S. 1971: Buffering techniques for hydrostatic systems at elevated pressures. In G. C. Ulmer (edit.) Research techniques for high pressures and temperatures, $367 \mathrm{pp}$. New York: Springer Verlag.

Konnerup-Madsen, J., Larsen, E. \& Rose-Hansen, J. 1979: Hydrocarbon-rich fluid inclusions in minerals from the alkaline Ilímaussaq intrusion, South Greenland. Bull. Soc. Min. Crist. 102, 642-653.

Lemoine, A. 1975: Contribution a l'etude du comportement de UO2 en milieux aqueux a haute temperature et haute pression. Unpubl. Ph.D. thesis, Nancy, $111 \mathrm{pp}$.

Makovicky, M. 1981: Preliminary results on the distribution of uranium in drill cores from Kvanefjeld, Ilímaussaq instrusion. Rapp. Grønlands geol. Unders. 103 (this volume).

Makovicky, M., Nielsen, B. L. \& Karup-Møller, S. 1979: Distribution of uranium in lujavrite from drill cores from Kvanefjeld. Unpubl. int. GGU rep., 42 pp.

8 Rapport nr. 103 
Naumov, G. B. 1961: Some physicochemical characteristics of the behavior of uranium in hydrothermal solutions. Geochemistry 2, 127-147.

Sørensen, H. 1962: On the occurrence of steenstrupine in the Ilimaussaq massif, Southwest Greenland. Bull. Grønlands geol. Unders. 32 (also Meddr Grønland 167,1) $251 \mathrm{pp.}$

Sørensen, H., Leonardsen, E. S. \& Petersen, O. V. 1970: Trona and thermonatrite from the Ilímaussaq alkaline intrusion, south Greenland. Bull. geol. Soc. Denmark 20,1-19.

Sørensen, H., Rose-Hansen, J. Nielsen, B. L., Løvborg, L., Sørensen, E. \& Lundgaard, T. 1974: The uranium deposit at Kvanefjeld, the Ilímaussaq intrusion, South Greenland. Geology, reserves and beneficiation. Rapp. Grønlands geol. Unders. 60, $54 \mathrm{pp}$.

Tuttle, O. F. 1949: Two pressure vessels for silicate-water studies. Bull. Geol. Soc. America 60, 1727 1729.

Ulmer, G. C. (edit.) 1971: Research techniques for high pressure and high temperature, $367 \mathrm{pp}$. New York: Springer Verlag.

Institut for Petrologi, University of Copenhagen, $\emptyset$ ster Voldgade 10, DK-1350 Copenhagen $\mathrm{K}$. 